\title{
IS IT POSSIBLE TO DEVELOP ENTREPRENEURSHIP AT SCHOOL?
}

\author{
M. Farnicka, I. Nowosad \\ Institute of Psychology, Zielona Góra University, Poland \\ m.farnicka@wpsnz.uz.zgora.pl
}

\begin{abstract}
Entrepreneurship will make it possible for young people to adapt to the employment market and participate in not only professional but also social and personal adult life effectively and satisfactorily. This article aimed to emphasize the way of developing entrepreneurship in the educational practice. The base of reflection as Culturally Relevant Pedagogy and Karney's definition of entrepreneurship. These approaches may open schools as environments for the coordination of all processes hidden in their culture on the way to effectiveness.

The category of entrepreneurship understood as a personal and organizational feature, an attitude, an activity mode, and a path of individual and institutional development were considered. When introducing challenges connected with the development of Entrepreneurship, some tools were described which make it possible to evaluate the changes taking place in the didactic process. This means that reflection on the process of development of must appears in various implementation spaces. It would be observable both at the level of individual development (students' and teachers' competencies), about activities undertaken within an organization, as well as changes in organizational climate and overall educational environment.
\end{abstract}

Keywords: cultural factors, innovation, entrepreneurship, school, teachers.

For citation: Farnika, M., Nowosad, I. (2021). Is it Possible to Develop Entrepreneurship at School? Respublica Literaria. Vol. 2. no. 2. pp. 98-112. DOI: 10.47850/RL.2021.2.2.98-112.

\section{Introduction}

The importance of developing entrepreneurship in educational institutions is associated with the dynamics of civilizational changes. Creativity and innovation have become objectives in undertaken practical or business activities, and they also determine the direction of changes in modern education. In numerous research publications on the effectiveness and development of the school, their authors discuss how the development of creativity may positively influence the quality of school and its educational offer [Robinson \& Azzam, 2009]. Young people need the ability to adapt to creating living, working, and learning conditions. The literature on the subject and the guidelines of the European Union [Parlament Europejski, 2006, p. 13] assume that entrepreneurship will make it possible for young people to adapt to employment markets and effectively participate in professional, social, and personal life. Moreover, some studies highlight that the most important feature of the modern human is the sentiment for the need for change (openness to change), which is manifested in demonstrating a predisposition to accept new ideas and undertake new operational methods. In this aspect, modern humans should be enterprising. 
The idea that a school is a good place for entrepreneurship development is based on a Culturally Relevant Pedagogy (CPR) [Brown-Jeffy \& Cooper, 2011, pp. 65-84.]. Model. This model indicates that education as a system has a significant relationship with its environment. The model is based on five independent, but mandatory elements. The first involves the identification of the identity of the participants in education and their culturally expected achievements. The second pillar of the presented approach is creating principles that provide equal opportunities to the participants of a given institution. The third element considers students' developmental potential when using tools and working methods, which are adequate to their developmental and psychological needs. This applies to relevant learning styles and techniques developed by teachers, as well as to skills related to motivating, engaging, cooperation, and communication. The next pillar concerns the culture of a given institution, which is manifested in its goals and values. Because specific tools are used in the context of the assumptions, relevant knowledge is transferred and its effects are evaluated. The final element is related to building relationships and atmosphere at school. One basic idea of that model may be paraphrased that the output of education depends on an adequate diagnosis of the relationship between educational institutions and their environment. In addition, this process is the basis for setting goals that could be achieved. A proper diagnosis is key to reveal suitable resources, advantages, and challenges.

In this article, entrepreneurship is understood as a personal feature, an attitude, a mode of activity, and a path of individual and institutional development is a focal point. And school is the place to develop these dimensions together with the student's interests and needs.

\section{What is entrepreneurship? - Basic definitions}

Although the literature repeatedly indicates the relationship between entrepreneurship and attitudes, skills, characteristics present in an individual, it is mainly seen as a form of work and a feature of organizations. In management theory, entrepreneurship is most often described as a personality feature. J. Kortan [1977, pp. 77-78] indicates that entrepreneurship is a behavioral model displaying a tendency to undertake new, risky and unconventional ventures, and showing initiative in their identification and implementation. In this approach, entrepreneurship can also be understood as competence or skill, which makes it possible for individuals to undertake an activity that denotes loyalty and consistency in pursuing a desired goal. Therefore, entrepreneurship [E] is not an activity in itself, but a readiness to act, resulting from a set of human personal qualities, skills and willpower to actively participate in life. It is a development-oriented activity and is characterized by innovation [1977, pp. 78-79]. Other authors stressed aspect of individual's feature ( $\mathrm{E}$ - dimensions in terms of activity - passivity, productivity - receptivity; $\mathrm{E}$ - readiness and ability to undertake, to solve new problems and use skills creatively and innovatively as well as to take advantage of emerging opportunities to flexibly adapt to the changing economic conditions, Drucker [1992]; E ability to see needs and improve ideas, and readiness to take risks, and institutional feature (E is a feature of an organization, a manner of its development, but also a human characteristic [Karney, 1997]). 
The following categories are used to describe entrepreneurship: features, competencies, skills, attitudes and operational modes within organizations. The categories often overlap and merge. A good example would be a definition of competence found in the Dictionary of Merriam-Webster (n.d.):

"Competences may be understood as features related to the way of thinking, creating relationships and acting in a way that affects the functioning of individuals in their professional lives. Competence is influenced by motivation, beliefs, experience and abilities as well as emotionality. Thus, the entrepreneurial feature would contain certain specific components such as commitment, flexibility, openness, vigilance, orientation on success, orientation on tasks, search for new things, etc.".

The term competence [Ekel et all, 1965, p. 22] is sometimes understood in terms of attitudes. In this sense, according to the definition of the term attitude, entrepreneurial competence would be a reflection of one's attitude to certain phenomena that arise throughout life based on three components: cognitive (knowledge), emotional (experience) and behavioral (operational mode).

Entrepreneurship as a competence. There are many meanings of entrepreneurial competence. One refers to specific rights to perform. Therefore, doctors' competence is their ability to write prescriptions because they have special powers to undertake such activities. In this sense, it can be indicated that a person is competent in a specific field of entrepreneurship, for example transporting people, goods, teaching others.

Another understanding of entrepreneurial competencies can be cited after Anna Matczak [Matczak, Martowska, 2009], who indicates a degree of certainty in knowledge and skills of how to act in a given field. In this understanding, people with certain competencies know what they can do, know how to use this knowledge, can perform and are sure that they will do well in certain situations.

Entrepreneurship as a feature. The psychological approach to features reveals that being a common property of many people; it may constitute a basis for comparison [Nuttin, 1968, pp. 3559, 238-286]. When comparing people, their otherness or similarity are emphasized. Individuals with common characteristics differ only in the degree of possession of these characteristics. Features are relatively constant characteristics within a tendency to specific forms of behavior, judgment or emotional reactions manifested in specific situations [Hall, Lindzey, 1990, pp. 409-410]. In this sense, according to Allport, entrepreneurship may be a central feature of an individual [Siek, 1993, p. 17]. This means that it should be treated as a certain instruction characterizing the individual's initiatives. According to Allport, dispositions are noticeable by the environment, because they are the most important defining features. A feature understood in this way is latent, which means that it cannot be directly observed, but only indicates its relationship with the observed behavior. Entrepreneurship understood as features may manifest itself as consistency, openness, activity or creativity.

Entrepreneurship as a feature of school culture reflects the current desire to create an active and innovative school. Therefore, it is a path shared by the school community which is to ensure the creation of a certain system of interactions securing a lasting effect within a given institution. 
Entrepreneurship is a skill. The categories: competencies and skills are very often used interchangeably as if they were synonymous. However, this is not the case. Competences and skills are different.

Skills are acquired through learning new things. They are relatively independent of our emotions or beliefs, although they are strongly associated with talent, features or predispositions for specific things. By investing a certain amount of energy and time, each person can acquire specific skills, although not everyone will have these skills developed at the same level. Therefore, skills can be learned based on individual potential. When using skills in entrepreneurship, the operational field is important: what am I good at? What can I do? At what level can I perform tasks, activities? In this sense, a person may have entrepreneurial skills, such as organizational skills, analytical or communication skills.

In this article, H. Karney's approach has been adopted. It indicates that entrepreneurship is a "feature of an organization, a path of its development, but also a human feature" [Karney, 1997]. Introducing challenges and some dimensions (as a tool) makes it possible to evaluate changes taking place in the didactic process. This means that reflection on the process of $\mathrm{E}$ development must occur in various implementation spaces. It would be observable in individual development (student's and teachers' competencies), in activities undertaken within an organization, as well as changes in organizational climate and overall educational environment.

\section{What could be entrepreneurship in school life?}

"Initiative and entrepreneurship" is one of eight key competencies defined by the European Union. According to the legislator, this competence denotes: "the ability to recognize and use opportunities, to implement ideas, to plan the process of implementation and to maintain this process to achieve goals" [Wojnarowska, 2016]. "The Entrepreneurship Competence Framework" defines entrepreneurship as "transversal competence which finds application in all spheres of life: from supporting personal development through active participation in social life, to (re)entering the employment market as an employee or as a self-employed individual and undertaking activities (cultural, social or commercial) within the market" [European, 2018]. In both documents, the competencies are defined as a combination of knowledge, skills and attitudes in the implementation of specific tasks.

Figure 1 schematically presents what should be considered when implementing entrepreneurship as an object of interest for educational institutions. Considering the multi-faceted and even hybrid nature of entrepreneurship, a degree of attention should be paid to the development of skills (range of features), competencies, behaviors, attitudes and effects (achievements and powers). 


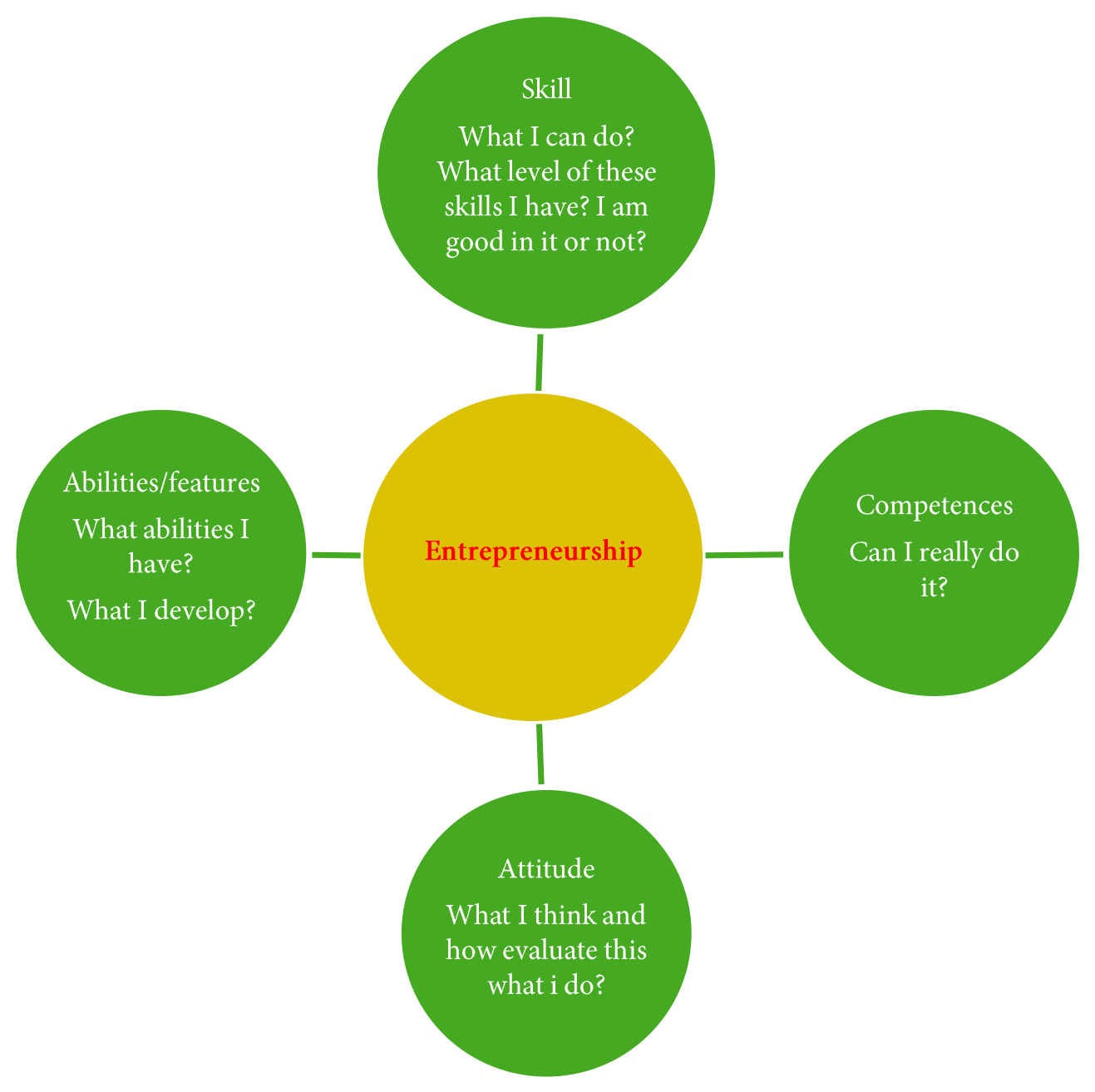

Fig. 1. A basic scope of tasks related to the development of entrepreneurship in educational institutions

To be more specific, in modern school, entrepreneurship combines the development of individual characteristics, acquired skills and shaped attitudes. Maria Łuczak [2013, pp. 87-120] described the development of this competence as broken down into two measurable components: knowledge and skills, and as related to individual (personal) features and attitudes. The compilation of that idea is presented in Fig. 2. 


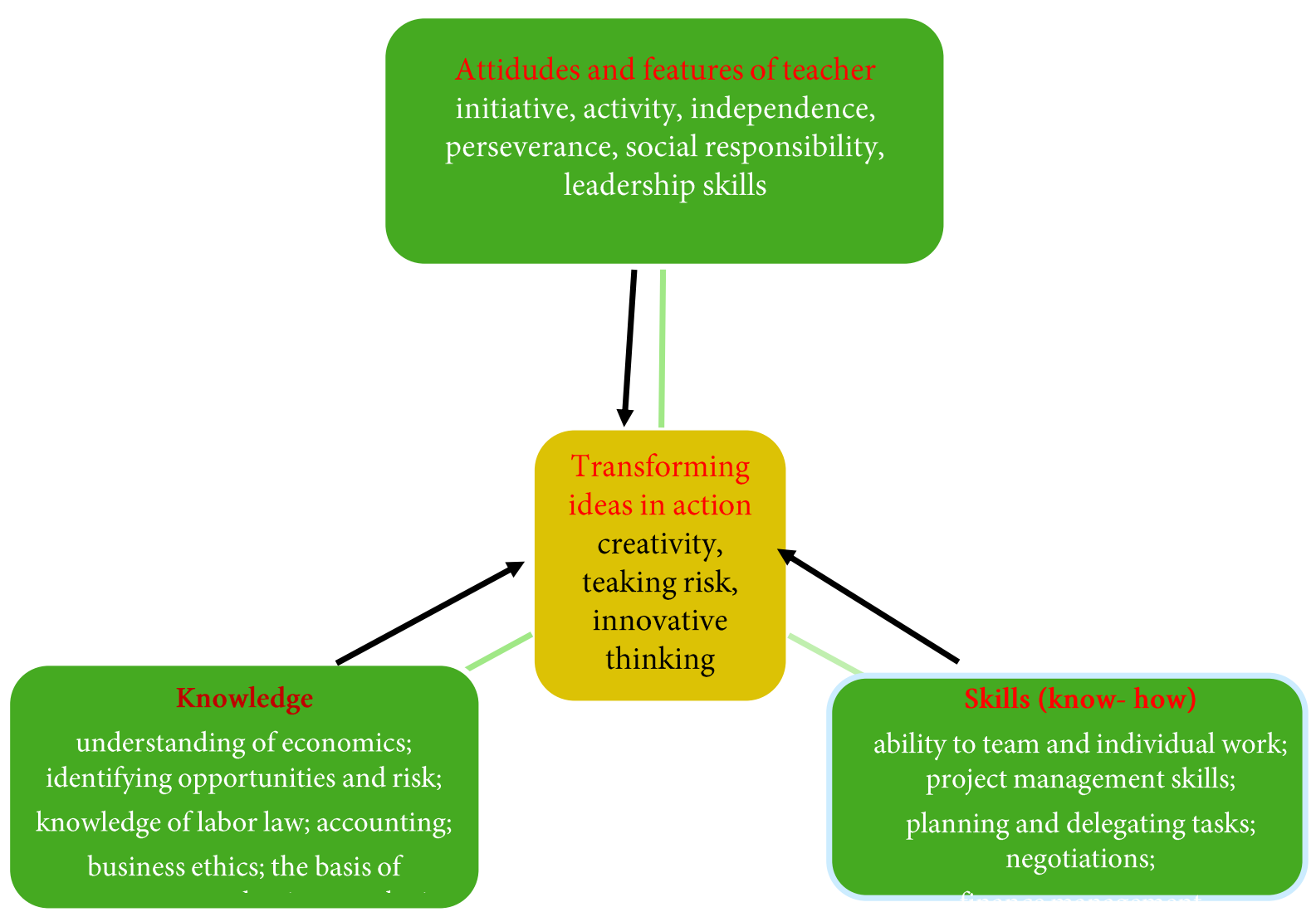

Fig. 2. Entrepreneurship as a key competence (knowledge, skills and attitudes)

Source: author's work based on Marta Łuczak, Teacher's role in shaping pupils' entrepreneurial attitudes.

The figure illustrates the dynamic nature of teachers' work. This work should be focused on: recognizing student attitudes, skills and abilities and forming a creative environment to activate real action (transforming thoughts, ideas into action and product); initiating, evaluating and supporting that process. The aim to "teach students to transform thoughts, ideas into action and product requires some specific knowledge, features, skills and attitudes from teachers. They are presented in Figure 2.

\section{Is it possible to teach entrepreneurship?}

Entrepreneurship is often connected with innovation and creativity. Now it is time to examine "why"?

Creativity understood as a product that is significant for society finds its exemplification in economic approaches. The economic approach to creativity focuses on three aspects - the impact of creativity on economic growth, methods of modelling creativity markets and maximizing economic creativity (innovation). Creativity leads to capital, and creative products are protected by intellectual property rights [Hargadon, Bechky, 2006]. Drucker tried to describe the "psycho-economic" model of creativity [1992]. In this model, creativity is a product of donations and active investment in creativity; the costs and benefits of introducing creative activity to the market determine the supply 
of creativity. In this approach, a creative person becomes a creator of innovative products and solutions, but he/she is also a kind of "product" of the impact and investment of the society in the development of creativity. Thus, a creative product (in a dual sense as a subject - creator, and an object - the result of a creative process and a real product) is determined by the potential and conditions created by the environment (resources, technological level, values, tools), skills to control and develop creative processes, which were acquired during education, personality traits, as well as intrapsychic conditions.

A meta-analysis conducted by Loo [2017] indicates that to create new and innovative products, cognitive abilities, personality, and specialist knowledge are used. The process of creating takes place both individually and collectively, which is why in its course non-individual conditions become important. To analyze various determinants of entrepreneurship and productivity, an integrative model of creativity determinants based on the "4P" model by Rhodes is presented [Garcês, Pocinho, Jesus, Viseu, 2016; Ricards, 1999]. According to that author, creativity is a result of the interaction of an individual's life context, his/her characteristics. The integrative model draws attention to the resources of the environment in which the features of the creative process and the specific characteristics of the product are rooted - the product that is made as a result of the creator's activity, but also as a result of the specific process and purpose of the action. In this approach, the non-linear direction of the analysis of the creative process and its products is assumed. Each element of the model is indispensable, irreplaceable and important at any moment for the creation of an effect. Individual characteristics are based on genetic conditions, but their expression is also a manifestation of specific conditions created by the context in which a given individual lives (this applies to historical, social and family context). The interaction between these two dimensions of the determinants of creativity determines the course of the creative process as well as its product. Integrating creativity education based on Rhodes' model focuses on developing creative capacities - skills and attitudes that contribute to imaginative, creative, and innovative thinking.

It is now recognized that innovation is not a component of creativity (and vice versa). It is believed that the difference between creativity and innovation is in their goals. Creativity is about liberating the potential of the mind to imagine new ideas. These can manifest themselves in many ways, but most often they become something that can be seen, heard, smelt, touched or tasted. Also, creative ideas can include experimental thoughts in the mind of one person. Innovation is completely measurable. It is about making changes in relatively stable systems. These changes may include producing something or making a correction in something that is already there. Identifying an unrecognized and unmet need, a person or organization uses their creative resources to introduce and test a change, i.e. innovation. It can therefore be said that creativity concerns the thinking process as well as production and implementation, while innovation uses creativity to introduce a new solution. If creativity does not include the production or implementation stage, only the characteristics of the individual or organization remain [Carlgren et al., 2016; Marshall, 2013]. 


\section{Signs of entrepreneurship at school}

\begin{tabular}{|c|c|c|c|}
\hline $\begin{array}{c}\text { Dimensions of } \\
\text { entrepreneurship }\end{array}$ & Student & Teacher & School \\
\hline Planning enterprises & $\begin{array}{l}\text { Initiates and implements } \\
\text { activities for his/her } \\
\text { development as well as the } \\
\text { development of the school and } \\
\text { local community }\end{array}$ & Creates conditions for ... & Awaits initiative, \\
\hline $\begin{array}{l}\text { The skill of setting } \\
\text { and achieving goals }\end{array}$ & $\begin{array}{l}\text { recognizes the resources and } \\
\text { needs of the environment; } \\
\text { shows determination and } \\
\text { consistency towards achieving } \\
\text { goals }\end{array}$ & $\begin{array}{l}\text { creates situations for ... } \\
\text { identifying needs and resources } \\
\text { in the environment; is } \\
\text { determined to bring projects to a } \\
\text { satisfactory conclusion }\end{array}$ & $\begin{array}{l}\text { is ready to send out } \\
\text { messages about } \\
\text { needs and is ready to } \\
\text { accept initiatives }\end{array}$ \\
\hline Activity & $\begin{array}{l}\text { becomes involved in } \\
\text { schoolwork and classwork; } \\
\text { works with others to solve } \\
\text { problems and achieve own } \\
\text { goals; } \\
\text { knows the meaning of self- } \\
\text { government and uses it } \\
\text { through his or her involvement }\end{array}$ & $\begin{array}{l}\text { creates situations for activity; } \\
\text { uses alternative, design and } \\
\text { problem methods; } \\
\text { creates situations to become } \\
\text { involved; } \\
\text { becomes involved, works in an } \\
\text { interdisciplinary manner; } \\
\text { motivates pupils to actively learn; } \\
\text { supports pupils in difficult } \\
\text { situations, creating an } \\
\text { atmosphere conducive to learning } \\
\text { competences; }\end{array}$ & $\begin{array}{l}\text { creates conditions } \\
\text { for teachers' own } \\
\text { and pupils' activity } \\
\ldots\end{array}$ \\
\hline Knowledge & $\begin{array}{l}\text { Knows the methods and } \\
\text { conditions for self- } \\
\text { development and development } \\
\text { of own creativity }\end{array}$ & $\begin{array}{l}\text { knows what entrepreneurship is; } \\
\text { knows ethics and labor law } \\
\text { knows the ways and conditions } \\
\text { for developing creativity in } \\
\text { himself and others, }\end{array}$ & $\begin{array}{l}\text { creates conditions } \\
\text { for acquiring and } \\
\text { deepening } \\
\text { knowledge } \\
\text { which has a positive } \\
\text { value }\end{array}$ \\
\hline
\end{tabular}




\begin{tabular}{|c|c|c|c|}
\hline Skills & $\begin{array}{l}\text { knows how to proactively } \\
\text { manage projects; plan, } \\
\text { organize, analyze conditions } \\
\text { and changes, communicate, } \\
\text { prepare reports, evaluate } \\
\text { activities; } \\
\text { can negotiate and present own } \\
\text { ideas and achievements; } \\
\text { can work individually and as a } \\
\text { team; } \\
\text { can recognize own strengths } \\
\text { and weaknesses; } \\
\text { knows how to assess risk in } \\
\text { creativity }\end{array}$ & $\begin{array}{l}\text { knows how to proactively } \\
\text { manage projects: plan, organize, } \\
\text { implement, divide tasks, analyze } \\
\text { conditions and changes, } \\
\text { communicate, prepare reports, } \\
\text { evaluate and monitor } \\
\text { negotiate and present own ideas } \\
\text { and achievements; } \\
\text { knows how to recognize } \\
\text { weaknesses and strengths in } \\
\text { projects; } \\
\text { can assess risk in } \\
\text { creativity }\end{array}$ & $\begin{array}{l}\text { positively values } \\
\text { skills; creates } \\
\text { conditions for } \\
\text { teachers and pupils } \\
\text { to develop }\end{array}$ \\
\hline Attitude & $\begin{array}{l}\text { creative; } \\
\text { proactive; } \\
\text { independent; } \\
\text { innovative; }\end{array}$ & $\begin{array}{l}\text { positively values attitudes; } \\
\text { creates conditions to pursue the } \\
\text { attitudes; models attitudes }\end{array}$ & $\begin{array}{l}\text { positively values } \\
\text { attitudes; } \\
\text { creates conditions } \\
\text { for implementing } \\
\text { teachers' and pupils' } \\
\text { attitudes }\end{array}$ \\
\hline
\end{tabular}

Source: author's study based on Nowosad, Farnicka [2019].

\section{Conclusions - Challenges to educational institutions}

Based on the presented challenges and tasks related to entrepreneurship listed in the table above, the question has been asked to define elements that are necessary for educational institutions to implement tasks that develop conditions favorable to entrepreneurship. The answers will be presented according to the CRP Model pillars [Brown- Jeffy, Cooper, 2011].

1) identification of the identity of the participants in education and their culturally expected achievements - Do we want to teach entrepreneurship? What do we understand?

2) creating principles that provide equal opportunities to develop entrepreneurship- How do we create challenges? How do we create an environment to develop the process of changing thoughts into a product? E is not a gift so it should be a skill and attitude.

3) development of students' potential when using tools and working methods that are adequate to their developmental and psychological needs - This applies to relevant learning styles and techniques developed by teachers, as well as to skills related to motivating, engaging, cooperation and communication. How do we support teachers to be good in that field?

What social and technological potential do we have?

4) goals and values inside the school - how and what is evaluated? What kind of work/product is good and efficient?

5) relationships and atmosphere at school - How can they be achieved? 
According to this assumption, the principles of environmental organization that directly supports the process of development of E at school could be established [Paulus, Dzindolet, 2008]. Following this way of thinking about entrepreneurship as an element of culture, basic conditions for its change should be indicated. The conditions for the development within institutions include:

1. Work has many stages. It has goals, creative and questioning phase, production and evaluation phases.

2. Physical learning environment allows for flexibility, so learners can work alone, in small groups, and in larger groups; they feel that they are a team, enriching the network of interpersonal relationships, increasing interaction, freedom of establishing close contacts.

3. They have tasks, plans, goals, rules of positive communication and stability and clarity of regulations.

3. Creative environment is welcoming; it is a place where learners feel safe to take risks;

4. All the time the environment itself is stimulating and may serve as a provocation for questions and investigations.

5. Learning often extends beyond the confines of the physical environment. The work finishes after real action and participants can evaluate each phase (as a process) and product at each stage and its value in the real market.

\section{Summary}

This article has implications for informal and formal lifelong learning of employees. Teaching institutions need to offer multi-disciplinary knowledge of humanities, arts and sciences, which should be reflected in course structures, teaching approaches and assessments. The article has also implications for the functioning of organizations that support and encourage collaborative work alongside individual initiatives, offer opportunities to engage in continuous professional development (formally and informally), and foster an environment that promotes experiential functioning and supports experimentation. Education focused on a specific problem-solving process, training and a specific climate conducive to creativity are essential. The presented framework is evidenced by empirical chapters on the micro-works of creative employees in the two knowledge economy sectors from global perspectives. The necessary conditions for creative work involve a supportive environment, such as an infrastructure of supportive information, communication and electronic technologies (ICET), training, work environment and education what is synergic with aspects of good conditions for learning and practice [Farnicka, Liberska 2014].

\section{The limitation of the model}

Unfortunately, according to the literature, there are two main limitations in E development: teachers and their limitations, and treating $\mathrm{E}$ as an apparent value and goal.

1. Teachers. To develop individual entrepreneurship, there must be a mental change, i.e. teachers must be convinced of its benefits and feel a real need for their development in this area. They must also apply it in practice after acquiring specific knowledge and skills. Currently, the manner of the development of key competencies as stipulated in the requirements for schools and educational institutions. Examples of tasks to be implemented to develop entrepreneurship as a key 
competence show that its development is possible when teachers create appropriate didactic situations. Preferably, they are situations in which pupils enjoy maximum independence and take matters into their own hands. They can co-decide what they will do, set goals, plan and organize their work, cooperate with others, reflect on their actions, correct them and draw conclusions. For teachers to be able to create such opportunities there should be a change in traditional roles between pupils and teachers. This opportunity is given by various educational methods, especially a project method known as "the queen of methods". Taking this approach as a starting point would include goal consolidation, task planning, task assignment, coordination (who, what, when, how), control and evaluation.

2. Apparent values - If the development of entrepreneurship is not to become yet another episode, there should be a change at the level of the institution, which denotes consolidation of positive evaluation of entrepreneurship and its manifestations. This applies to the declarative (regulations), organizational as well as structural and cultural layers covering the deepest levels of recognized patterns and values [Fullan, 2001; Fullan, 2003]. In addition, the development towards entrepreneurship involves a change of symbolic order: from fragmentary individualism to the culture of cooperation, which requires openness, trust and commitment. Is it possible to develop entrepreneurship at the institutional level?

H. Karney's approach was adopted, indicating that entrepreneurship is a "feature of an organization, a path of its development, but also a human feature" [1997]. We are convinced that development in this direction is possible at schools. To support processes related to building an entrepreneurial culture based on the values of trust, openness and initiative, we may use a tool known as educational research in action. Introducing changes employing this tool makes it possible to evaluate changes taking place in various dimensions and at different times. This means that reflection on this process must appear in various implementation areas. It would be observable both at the level of individual development (pupils' and teachers' competencies), activities are undertaken within an organization, as well as changes in organizational climate and overall educational environment.

\section{References}

Абрамова, М.А., Крашенинников, В.В., Либерска, Х., Фарника, М. (2015). Трансляция культуры и/или развитие в деятельности: германо-российская и англо-саксонская модели образования. Философия образования. № 2 (59). С. 37-45.

Abramova M.A., Krasheninnikov V.V., Liberskaya Kh., Farnika M. (2015). Translation of culture and / or development in activity: German-Russian and Anglo-Saxon models of education. Philosophy of education. no. 2 (59). pp. 37-45. (In Russ.)

Каменев, Р.В., Крашенинников, В.В., Фарника, М., Абрамова, М.А. (2018). Высокие технологии и трансформация системы образования: конструктивность и деструктивность. Вестник Новосибирского государственного педагогического университета. Т. 8. № 6. С. 104119. 
Kamenev, R.V., Krasheninnikov, V.V., Farnika, M., Abramova, M.A. (2018). High technologies and the transformation of the education system: constructiveness and destructiveness. Bulletin of the Novosibirsk State Pedagogical University. Vol. 8. no. 6. pp. 104-119. (In Russ.)

Brown-Jeffy, S., Cooper, J.E. (2011). Toward a Conceptual Framework of Culturally Relevant Pedagogy: An Overview of the Conceptual and Theoretical Literature. Teacher Education Quarterly. Vol. 38. no. 1. pp. 65-84.

Carlgren, L., Rauth, I., Elmquist, M. (2016). Framing Design Thinking: The Concept. In: Idea and Enactment. Creativity and Innovation Canagement. Vol.25(1), pp.38-57. DOI: $10.1111 /$ caim.12153.

Drucker, P.F. (1992). Innowacja i przedsiębiorczość. Praktyka i zasady. Transl. A. Ehrlich. Warszawa.

Drucker, P.F. (1992). Innovation and entrepreneurship. Practice and rules. Transl. A. Ehrlich. Warsaw. (In Polish)

Ekel, J., Jaroszyński, J., Ostaszewska. J. (1965). Mały słownik psychologiczny. Warszawa.

Ekel, J., Jaroszyński, J., Ostaszewska. J. (1965). A little psychological dictionary. Warsaw. (In Polish)

Zalecenia Ready Europejskiej w sprawie kompetencji kluczowych. (2018). Dziennik Urzędowy Unii Europejskie. №4.6. C189/1-189/13. [Электронный pecypc]. URL: https:/eurlex.europa.eu/legal-content/PL/TXT/PDF/?uri=CELEX:32018H0604(01)\&from=EN (дата обращения 25.01.2021).

European Ready Recommendations on Key Competences. (2018). Official Journal of the European Union. no. 4.6. C189/1-189/13. [Online]. Available at: https://eur-lex.europa.eu/legalcontent/PL/TXT/PDF/?uri=CELEX:32018H0604(01)\&from=EN (Accessed: 25 January 2021). (In Polish)

Farnicka, M., Liberska, H. (2014). Tworzenie środowiska sprzyjającego uczeniu się - analiza psychologiczna. Teraźniejszość- Człowiek - Edukacja. no. 67 (3). pp. 57-71.

Farnicka, M., Liberska, H. (2014). Creating an environment conducive to learningpsychological analysis. The Present-Man-Education. no. 67 (3).pp. 57-71. (In Polish)

Fullan, M. (2001). Leading in a culture of change: being effective in complex times. San Francisco.

Fullan, M. (2003). Change forces with a vengeance. London. Routhledge Falmer. DOI:10.4324/9780203165805. 
Garcês, S., Pocinho, M., Jesus, S.N., Viseu, J. (2016), The Impact of the Creative Environment on the Creative Person, Process, and Product. Avaliação Psicológica. no. 15(2), pp. 169-176.

Hall, C. S., Lindzey, G. (2001). Teorie osobowości. Warszawa.

Hall, C. S., Lindzey, G. (2001). Personality theory. Warsaw. (In Polish)

Hargadon, A.B., Bechky, B.A. (2006). When collections of creatives become creative collectives: A field study of problem solving at work. Organization Science. Vol. 17. no. 4. pp. 484500. DOI:10.1287/orsc. 1060.0200

Karney, H. (1997). Psychopedagogika pracy. Gdansk.

Karney, H. (1997). Psychopedagogy of work. Gdansk.

Kortan, J. (eds.) (1997). Podstawy ekonomiki i zarządzania przedsiębiorstwem, Wydawnictwo C. H. Beck, Warszawa.

Kortan J. (eds.) (1997). Fundamentals of economics and business management, Wydawnictwo C. H. Beck, Warsaw.

Loo, S. (2017), Creative Working in the Knowledge Economy. [Online]. Available at: https://www.routledge.com/Creative-Working-in-the-Knowledge-Economy/ Loo/p/book/9781138211391. (Accessed: 16 May 2021).

Łuczak, M. za: Nowosad, I., Uździcki, R. (2013). Innowacje miara rozwoju szkolnej kultury przedsiebiorczosci. W: Nowosad, I., Karmolińska-Jagodzik E. (red.). Potencjał szkoły w tworzeniu więzi ze środowiskiem, Wydawnictwo Wyższej Szkoły Humanistycznej im. Króla Stanisława Leszczyńskiego, Lesznopp. pp. 87-120.

Luczak, M. (2013). Innovations a measure of the development of school culture of entrepreneurship. In: I. Novosad, E. Karmolińska-Jagodzik (eds.). The potential of the school in creating links with the environment. Leszno. King Stanisław leszczyński WWSH in Leszno, 2013, pp. 87-120. (In Polish)

Matczak, A., Martowska, K. (2009). Instrumental and motivational determinants of social competencies. W: A. Matczak (ed.). Determinants of social and emotional competencies. Warszawa. Wydawnictwo Uniwersytetu Kardynała Stefana Wyszyńskiego.

Matczak, A., Martowska, K. (2009). Instrumental and motivational determinants of social competences. In: A. Matczak (ed.). Determinants of social and emotional competencies. Warszawa: Wydawnictwo Uniwersytetu Kardynała Stefana Wyszyńskiego. (In Polish)

Marshall, D. (2013). There's a Critical Difference Between Creativity and Innovation. Business Insider, Primed Associates. [Online]. Available at: https://www.businessinsider.com/differencebetween-creativity-and-innovation-2013-4\#ixzz2w0virpal (Accessed: 6 May 2021). 
Competence. In: Merriam-Webster.com dictionary. [Online]. Available at: www.merriamwebster.com/dictionary/competence. (Accessed: 1 June 2021).

Nowosad, I. Farnicka, M. (2019). Entrepreneurship at school. Is institutional development of entrepreneurship possible? In: M. Zapotoczna (ed.). International Forum for Education. no. 12. pp. 103-116. Toruń. Marszalek Press. DOI: 10.15804/IFforE2019.06

Nuttin, J. (1968). Struktura osobowości. Warszawa.

Nuttin, J. (1968). Personality structure. Warsaw. (In Polish)

Nuttin, J. (1968). Personality structure. Warsaw.

Parlament Europejski i Rada Europy z 2006 r. (Dz.U. L 394 z 30.12.2006, p. 13).

European Parliament and council of Europe, 2006 (OJ 1 394, 30.12.2006, p.13). (In Polish)

Paulus, P.B., Dzindolet, M. (2008). Social influence, creativity and innovation. Social Influence. Vol. 3. no. 4. pp. 228-247. DOI: 10.1080/15534510802341082.

Ricards, T. (1999). Creativity and the management of change. Blackwell Publishers, NY.

Robinson, K., Azzam, A.M. (2009). Why creativity now? Educational Leadership. Vol. 67. no. 1, pp. 22-26.

Siek, St. (1993). Wybrane metody badania osobowości. Warszawa.

Siek, St. (1993). Selected methods of personality testing. Warsaw. (In Polish)

Wojnarowska, M. (2016) Kompetencje kluczowe- przygotowanie do życia. Trendy. no. 4. pp. 4-11. [Электронный pecypc]. URL: accessed from: http: //www.bc.ore.edu.pl/Content/893/T416_Kompetencje+kluczowe_przygotowanie+do+zycia.pdf (дата обращения 20.04.2021).

Wojnarowska, M. (2016) Key competences-preparation for life. Trends. no. 4. pp.4-11. [Online]. Available at: http://www.bc.ore.edu.pl/Content/893/T416_Kompetencje key preparation for life.pdf (Accessed: 20 April 2021).

\section{Сведения об авторах}

Marzanna Farnicka - Professor (Adjunct), Head of Family Psychology Unit, Institute of Psychology, Zielona Góra University, 65-417 Zielona Góra, Poland. http://orcid.org/0000-00024274-1646. E-mail: m.farnicka@wpsnz.uz.zgora.pl 
Inetta Nowosad - Professor (Associate), Institute of Pedagogy, Zielona Góra University, 65417 Zielona Góra, Poland. https://orcid.org/0000-0002-3739-7844. E-mail: i.nowosad@wns.uz.zgora.pl

The paper was submitted: 30.04 .2021

Received after reworking: 26.05 .2021

Accepted for publication: 07.06.2021 